\title{
An Overview of Four Issues on Technology Entrepreneurship in the TIM Review
}

\author{
Tony Bailetti, Sonia Bot, Tom Duxbury, David Hudson, Chris McPhee, \\ Steven Muegge, Michael Weiss, Jonathan Wells, and Mika Westerlund
}

\author{
(6 Discovery consists of seeing what everybody has seen and") \\ thinking what nobody has thought. \\ Albert Szent-Györgyi \\ Physiologist and Nobel Laureate (1937)
}

\begin{abstract}
The field of technology entrepreneurship is in its infancy when compared to other fields such as economics and management. Articles on technology entrepreneurship have been published in at least 62 journals, of which only 18 contribute to technology innovation management or entrepreneurship. Less than a handful of these 62 journals are considered to be "good" journals and none can claim a leadership position in technology entrepreneurship. The purpose of this article is to provide an overview of the 20 journal articles published in the February, March, April, and May 2012 issues of the Technology Innovation Management Review (TIM Review).
\end{abstract}

\section{Introduction}

Technology entrepreneurship is an investment in a project that assembles and deploys specialized individuals and heterogeneous assets that are intricately related to advances in scientific and technological knowledge for the purpose of creating and capturing value for a firm (Bailetti, 2012; timreview.ca/article/520). Technology entrepreneurship applies equally well to newly formed or established firms as well as firms of any size.

The study of technology entrepreneurship serves an important function beyond satisfying intellectual curiosity. Technology entrepreneurship is necessary for growth, differentiation, and competitive advantage at the firm, regional, and national levels (Bailetti, 2012).

In early September 2011, a request for articles on technology entrepreneurship was issued to the faculty, staff, doctoral and master students, and professionals associated with Carleton University's Technology Innovation Management program (carleton.ca/tim) with the intent of producing a special issue of the TIM Review on the theme of technology entrepreneurship. Given the over- whelming response to this request and the perceived importance of the topic, four consecutive issues focusing on technology entrepreneurship were published in early 2012.

In this article, the 20 journal articles published in the February, March, April and May 2012 issues of the TIM Review - and listed in Table 1 - are classified based on the subject matter and main objective of the article. Next, four salient aspects of the set of 20 journal articles are discussed. Finally, the last section provides our conclusions.

\section{Journal Articles by Themes}

Table 2 organizes the 20 articles published in the February to May 2012 issues of the TIM Review into nine themes. The first eight themes in Table 2 were those used to organize the 93 articles on technology entrepreneurship published since 1970 reviewed by Bailetti (2012; timreview.ca/article/520). The ninth theme, Theory advancement, is new. The new theme was added because three articles in the TIM Review dealt with building theory more than with the topics included in the other themes. 


\section{An Overview of Four Issues on Technology Entrepreneurship in the TIM Review}

Bailetti, Bot, Duxbury, Hudson, McPhee, Muegge, Weiss, Wells, and Westerlund

Table 1. The 20 articles published in the TIM Review from February to May 2012

\begin{tabular}{|c|c|c|}
\hline Issue & Article Title & Author(s) and Link to Article \\
\hline \multirow[t]{5}{*}{ February } & $\begin{array}{l}\text { 1. Technology Entrepreneurship: Overview, Definition, and } \\
\text { Distinctive Aspects }\end{array}$ & Bailetti (2012; timreview.ca/article/520) \\
\hline & 2. Entrepreneurial Effort in the Theory of the Firm & Hudson $(2012 ; 521)$ \\
\hline & $\begin{array}{l}\text { 3. Organizational Ambidexterity: How Small Technology } \\
\text { Firms Balance Innovation and Support }\end{array}$ & Schreuders and Legesse $(2012 ; 522)$ \\
\hline & 4. Social Entrepreneurship: Definition and Boundaries & Abu-Saifan (2012; 523) \\
\hline & 5. Chinese Entrepreneurs Go Global & Zhou $(2012 ; 524)$ \\
\hline \multirow[t]{5}{*}{ March } & $\begin{array}{l}\text { 6. Global from the Start: The Characteristics of Born-Global } \\
\text { Firms in the Technology Sector }\end{array}$ & Tanev $(2012 ; 532)$ \\
\hline & 7. Towards More Case Study Research in Entrepreneurship & Duxbury $(2012 ; 533)$ \\
\hline & $\begin{array}{l}\text { 8. A Customer Value Creation Framework for Businesses } \\
\text { That Generate Revenue with Open Source Software }\end{array}$ & Shanker $(2012 ; 534)$ \\
\hline & $\begin{array}{l}\text { 9. Minimum Viable Product and the Importance of } \\
\text { Experimentation in Technology Startups }\end{array}$ & Rancic Moogk (2012; 535) \\
\hline & 10.A Guide for Entrepreneurs Who Lead and Manage Change & Plante $(2012 ; 536)$ \\
\hline \multirow[t]{5}{*}{ April } & 11.Business Model Discovery by Technology Entrepreneurs & Muegge (2012; 545) \\
\hline & 12. User Frustrations as Opportunities & Weiss $(2012 ; 546)$ \\
\hline & 13. Process Ambidexterity for Entrepreneurial Firms & Bot $(2012 ; 547)$ \\
\hline & $\begin{array}{l}\text { 14. How Do Large Companies Manage Their Investments } \\
\text { Across the Three Horizons? }\end{array}$ & Carbone $(2012 ; 548)$ \\
\hline & 15. The Role of Universities in Technology Entrepreneurship & Wells (2012; 549) \\
\hline \multirow[t]{5}{*}{ May } & 16. Categorizing the Growth Strategies of Small Firms & Leminen and Westerlund (2012; 553) \\
\hline & $\begin{array}{l}\text { 17. Results-Based Organization Design for Technology } \\
\text { Entrepreneurs }\end{array}$ & McPhee $(2012 ; 554)$ \\
\hline & $\begin{array}{l}\text { 18. Making Money from Exploiting Schumpeterian } \\
\text { Opportunities: John Sanguinetti and the Electronic Design } \\
\text { Automation Industry }\end{array}$ & Low $(2012 ; 555)$ \\
\hline & $\begin{array}{l}\text { 19. Applying the Theory of the Firm to Examine a Technology } \\
\text { Startup at the Investment Stage }\end{array}$ & Ayukawa $(2012 ; 556)$ \\
\hline & $\begin{array}{l}\text { 20. An Overview of Four Issues on Technology } \\
\text { Entrepreneurship in the TIM Review }\end{array}$ & Bailetti et al. (2012; 557) \\
\hline
\end{tabular}




\section{An Overview of Four Issues on Technology Entrepreneurship in the TIM Review}

Bailetti, Bot, Duxbury, Hudson, McPhee, Muegge, Weiss, Wells, and Westerlund

Table 2. Themes contained in TIM Review articles from February to May 2012

\begin{tabular}{|c|c|c|c|c|}
\hline & Themes & References & $\begin{array}{l}\text { \# of Journal } \\
\text { Articles }\end{array}$ & $\begin{array}{l}\text { \% of } \\
\text { Total }\end{array}$ \\
\hline 1 & $\begin{array}{l}\text { External factors that influence formation of } \\
\text { technology firms }\end{array}$ & - Wells (2012) & 1 & $5 \%$ \\
\hline 2 & $\begin{array}{l}\text { How, why, and when technology } \\
\text { entrepreneurship affects the socio-economic } \\
\text { development of a region }\end{array}$ & - $\mathrm{n} / \mathrm{a}$ & 0 & $0 \%$ \\
\hline 3 & $\begin{array}{l}\text { Approaches used by small technology firms to } \\
\text { generate revenue and reduce costs }\end{array}$ & $\begin{array}{l}\text { - Muegge (2012) } \\
\text { - Rancic Moogk (2012) } \\
\text { - Shanker (2012) } \\
\text { - Weiss (2012) }\end{array}$ & 4 & $20 \%$ \\
\hline 4 & $\begin{array}{l}\text { Internal practices used to operate and } \\
\text { transform small technology firms }\end{array}$ & $\begin{array}{l}\text { - McPhee (2012) } \\
\text { - Plante (2012) } \\
\text { - Schreuders \& Legesse (2012) }\end{array}$ & 3 & $15 \%$ \\
\hline 5 & $\begin{array}{l}\text { Interdependence between technology path and } \\
\text { small technology firm formation and growth }\end{array}$ & $\begin{array}{l}\text { - Leminen \& Westerlund (2012) } \\
\text { - Low (2012) }\end{array}$ & 2 & $10 \%$ \\
\hline 6 & $\begin{array}{l}\text { Overview of technology and social } \\
\text { entrepreneurship }\end{array}$ & $\begin{array}{l}\text { - Abu-Saifan, 2012) } \\
\text { - Bailetti (2012) } \\
\text { - Bailetti et al. (2012) }\end{array}$ & 3 & $15 \%$ \\
\hline 7 & $\begin{array}{l}\text { Corporate entrepreneurship function in mid- } \\
\text { sized and large firms }\end{array}$ & $\begin{array}{l}\text { - Bot (2012) } \\
\text { - Carbone (2012) }\end{array}$ & 2 & $10 \%$ \\
\hline 8 & Contributions to closely related fields & $\begin{array}{l}\text { - Tanev (2012) } \\
\text { - Zhou (2012) }\end{array}$ & 2 & $10 \%$ \\
\hline \multirow[t]{2}{*}{9} & Theory advancement & $\begin{array}{l}\text { - Ayukawa (2012) } \\
\text { - Duxbury (2012) } \\
\text { - Hudson (2012) }\end{array}$ & 3 & $15 \%$ \\
\hline & & Total & 20 & $100 \%$ \\
\hline
\end{tabular}




\section{An Overview of Four Issues on Technology Entrepreneurship in the TIM Review} Bailetti, Bot, Duxbury, Hudson, McPhee, Muegge, Weiss, Wells, and Westerlund

\section{Journal Articles by Main Objective}

Table 3 identifies the main objectives of the 20 articles on technology entrepreneurship published in the February to May issues of the TIM Review. The following subsections more closely examine each objective.

\section{Provide solutions to problems faced by technology en- trepreneurs}

Ten articles described approaches, frameworks, guides, mechanisms, models, or tools that technology entrepreneurs can use to solve eight of the problems they face. Table 4 identifies the eight distinct problems and matched them against the 10 articles that propose solutions in the context of technology entrepreneurship.

These articles cover the complement of articles in the following three themes from Table 2: Approaches used by small technology firms to generate revenue and reduce costs, Internal practices used to operate and transform small technology firms, and Corporate entrepreneurship function in mid-sized and large firms.

\section{Advance theory to help technology entrepreneurship}

Three articles focused on advancing theory of entrepreneurship. The process of building theory can be conceptualized as comprised of four components: i) theory
Table 3. Main objectives of 20 TIM Review articles

\begin{tabular}{clcc}
\hline & Main Objective & $\begin{array}{c}\text { \# of } \\
\text { Articles }\end{array}$ & \% \\
\hline 1 & $\begin{array}{l}\text { Provide solutions to } \\
\text { problems faced by } \\
\text { technology } \\
\text { entrepreneurs }\end{array}$ & 10 & $50 \%$ \\
\hline 2 & $\begin{array}{l}\text { Advance theory to help } \\
\text { technology } \\
\text { entrepreneurs }\end{array}$ & 3 & $15 \%$ \\
\hline 3 & $\begin{array}{l}\text { Scope and define the } \\
\text { fields of technology and } \\
\text { social entrepreneurship }\end{array}$ & 3 & $15 \%$ \\
\hline 4 & $\begin{array}{l}\text { Leverage salient } \\
\text { features of international } \\
\text { entrepreneurship }\end{array}$ & 2 & $10 \%$ \\
\hline 5 & $\begin{array}{l}\text { Provide lessons from } \\
\text { experience }\end{array}$ & 2 & $10 \%$ \\
\hline & $\quad$ Total & $\mathbf{2 0}$ \\
\hline
\end{tabular}

Table 4. Articles that address solutions to problems faced by technology entrepreneurs

\begin{tabular}{|c|c|c|}
\hline & Problem & Articles with Solutions \\
\hline 1 & Developing a successful business model & - $\quad$ Muegge (2012) \\
\hline 2 & Discovering business opportunities & - Weiss (2012) \\
\hline 3 & Testing a new product's fit to a market and its growth projections & - $\quad$ Rancic Moogk (2012) \\
\hline 4 & Balancing initiatives to exploit vs. initiatives to explore & $\begin{array}{ll}- & \text { Bot (2012) } \\
\text { - } & \text { Carbone (2012) } \\
\text { - } & \text { Schreuders \& Legesse (2012) }\end{array}$ \\
\hline 5 & Designing firms to deliver desired outcomes & - $\quad$ McPhee (2012) \\
\hline 6 & Leading and managing change to grow a firm & - $\quad$ Plante (2012) \\
\hline 7 & Attaining a firm's goals for revenue and volume & - $\quad$ Leminen \& Westerlund (2012) \\
\hline 8 & Generating revenue from the use of open source assets & - Shanker (2012) \\
\hline
\end{tabular}




\title{
An Overview of Four Issues on Technology Entrepreneurship in the TIM Review
}

\author{
Bailetti, Bot, Duxbury, Hudson, McPhee, Muegge, Weiss, Wells, and Westerlund
}

formation, ii) categorization, iii) observation and description, and iv) research tools. Table 5 shows the articles on theory building by component.

Table 5. Articles on theory building

\begin{tabular}{lll}
\hline & Component & Articles \\
\hline 1 & Theory formation & Hudson (2012) \\
\hline 2 & Categorization & $\mathrm{n} / \mathrm{a}$ \\
\hline 3 & Observation and description & Ayukawa (2012) \\
\hline 4 & Research tools & Duxbury (2012) \\
\hline
\end{tabular}

Of these three articles, two describe the link between the theory of the firm and entrepreneurship (Ayukawa, 2012; timreview.ca/article/556; Hudson, 2012; timreview.ca/ article/521); one argues for greater use of case research to develop theory of entrepreneurship (Duxbury, 2012; timreview.ca/article/533).

Of the two articles that describe the link between the theory of the firm and entrepreneurship, one is focused on entrepreneurial employees of large companies (Hudson, 2012; timreview.ca/article/521), while the other one examines the investment stage of new technology companies (Ayukawa, 2012; timreview.ca/article/556).

\section{Scope and define the field}

The first article in the four-issue series on technology entrepreneurship reviewed the articles published over the last 40 years, proposed a definition of technology entrepreneurship, and described its distinguishing aspects (Bailetti, 2012; timreview.ca/article/520). In this last article, we examine what was published in the past four issues of the TIM Review (Bailetti et al., 2012; timreview.ca/article/557).

One article defines social entrepreneurship, examines the boundaries of socially-oriented entrepreneurial activities, and positions the social entrepreneur in the spectrum of entrepreneurship (Abu-Saifan, 2012; timreview.ca/article/523).

\section{Leverage salient features of international entrepren- eurship}

Two articles focus on international aspects of entrepreneurship. Tanev (2012, timreview.ca/article/532) de- scribes the characteristics of technology firms designed to be global upfront. Zhou (2012; timreview.ca/article/524) uses the Kirznerian and Schumpeterian perspectives of entrepreneurship to examine the "go global" initiatives of Chinese entrepreneurs and describes the unique characteristics of the business environment and culture in China, which are likely to motivate Chinese entrepreneurs to go global.

\section{Lessons from experience}

Two articles describe lessons gained from industry experience. Low (2012; timreview.ca/article/555) identifies the lessons learned from examining the effect that two companies had on the market for integrated circuit design languages. Wells (2012; timreview.ca/article/549) examines the role universities play helping entrepreneurs launch and grow their businesses.

\section{Salient Aspects}

Four factors distinguished the set of 20 articles published in the TIM Review from the 93 articles published from 1970 to 2011.

\section{Oriented to solving real problems}

Over the last 40 years, the technology entrepreneurship literature has been dominated by a theme that focuses on identifying the antecedents and consequences of technology firm formation. Of the 93 earlier papers reviewed, $42(45 \%)$ were classified under this theme (Bailetti, 2012; timreview.ca/article/520); in contrast, only one of the 20 papers (5\%) published in the TIM Review focused on this theme (Table 2).

The articles published in the TIM Review are dedicated to solving a diverse set of real problems encountered by entrepreneurs in small and large companies. Table 3 shows that $50 \%$ of the TIM Review articles proposed solutions to problems faced by entrepreneurs. Table 4 indicates that these articles addressed solutions to diverse problems.

It is interesting to note that none of the TIM Review articles fall within the second theme in Table 2, How, why and when technology entrepreneurship affects the socio-economic development of a region, despite the fact that the TIM Review articles are from people associated with a particular geographic region in Canada that has a history of technology firms and a base of governmentsponsored research laboratories. This suggests that while the TIM Review articles are oriented to solving real problems, the interest is in problems that are not idiosyncratic to a specific company, technology sector, 


\title{
An Overview of Four Issues on Technology Entrepreneurship in the TIM Review
}

\author{
Bailetti, Bot, Duxbury, Hudson, McPhee, Muegge, Weiss, Wells, and Westerlund
}

governmental policy, or metropolitan area despite ready access to potential case study material in that geographic region.

\section{Contributed to theory building}

While there is nothing more practical than a good theory (Lewin, 1952; tinyurl.com/brzkmvl), not one of the 93 articles reviewed by Bailetti (2012; timreview.ca/article/520) stated that the advancement of the theory of technology entrepreneurship was its main objective. In contrast, three of the 20 articles published in the TIM Review contributed to the advancement of theory of entrepreneurship.

Two articles provided new ideas for understanding, conceptualizing, and dealing with problematic situations (Ayukawa, 2012: timreview.ca/article/556; Hudson, 2012: timreview.ca/article/521). One article provided researchers with key information and facts relevant to carrying out research in technology entrepreneurship (Duxbury, 2012; timreview.ca/article/533).

\section{Greater focus on profiting from filling gaps in existing systems rather than on profiting from creative destruction The technology entrepreneurship literature published from 1970 to 2010 as well as the 20 articles published in the TIM Review deal with problems associated with the production and adoption of radical innovations. Only one of the 20 articles published in the TIM Review fo- cused on influencing or causing creative destruction.}

This suggests that the articles published in the TIM Review take a view of entrepreneurship that encompasses a wider range of potential actions than would be associated with rare disruptions of economy-wide equilibrium (Schumpeter, 1950; tinyurl.com/cka78wt). Entrepreneurship applies to a broad group of individuals in a variety of roles (Shane, 2012; tinyurl.com/bn3vp9g) including those engaged in "occupational entrepreneuring" (Courpasson, Dany \& Marti, 2011; tinyurl.com/dx9z9y4) addressing more everyday opportunities in existing systems.

The TIM Review content has taken a view of entrepreneurship that is broad however most of what has been published to date focuses on profiting from opportunities to fill gaps in existing economic systems and even in existing firms. Consequently profiting from the rare but immensely valuable "big bangs" (Perez, 2009; tinyurl.com/cun7j4n) has largely been ignored.

\section{Existence of critical mass}

A total of 21 authors contributed 20 articles to the four issues on technology entrepreneurship and Tables 1 through 5 are evidence that sufficient quantity and diversity of contributors of journal articles with innovative ideas exists. If this continues, it is expected that the rate of innovative contributions can become self sustaining and create further growth in knowledge.

\section{Conclusions}

Faculty, students, staff and professionals associated with Carleton University's TIM program contributed 19 articles on technology entrepreneurship and one article on social entrepreneurship to the TIM Review. The 20 articles published in the February, March, April and May 2012 issues were classified based on themes and the article's main objective. The set of 20 articles published in the TIM Review were oriented more towards contributing solutions to real problems faced by technology entrepreneurs and advancing theory than those reviewed by Bailetti (2012; timreview.ca/article/520).

Two aspects require particular attention. A major effort must be dedicated to producing TIM Review content that helps technology entrepreneurs profit from creative destruction opportunities (Schumpeter, 1950; tinyurl.com/cka78wt). Most of what has been published on technology entrepreneurship to date has focused on profiting from opportunities to fill gaps in the existing economic system. A second major effort needs to focus on global entrepreneurship, particularly what can be done to decrease the time to cash from sales to foreign customers. How can we design technology companies so they can operate globally shortly after they are launched?

\section{About the Authors}

Tony Bailetti is an Associate Professor in the Sprott School of Business and the Department of Systems and Computer Engineering at Carleton University, Ottawa, Canada. Professor Bailetti is the Director of Carleton University's Technology Innovation Management program. His research, teaching, and community contributions support technology entrepreneurship, regional economic development, and international co-innovation. 


\section{An Overview of Four Issues on Technology Entrepreneurship in the TIM Review}

Bailetti, Bot, Duxbury, Hudson, McPhee, Muegge, Weiss, Wells, and Westerlund

Sonia Bot is a business executive that specializes in strategy and business execution for technology innovation and corporate entrepreneurship ventures. She has extensive experience in the high-tech industry, including business transformation and strategy, product management and delivery, and new venture creation within multinational technology companies. Her work experience includes Research In Motion, Nortel, Bell-Northern Research, IBM, and TransCanada Pipelines. She holds degrees in Computer Science with Systems Design / Electrical Engineering (BMath) from the University of Waterloo and Biomedical Engineering (MASc) from the University of Toronto, and she is a certified Lean Six Sigma Master Black Belt.

Tom Duxbury is Entrepreneur in Residence at Wesley Clover Technologies, a private equity incubator. $\mathrm{He}$ is currently completing his $\mathrm{PhD}$ in Management at the Sprott School of Business at Carleton University in Ottawa, where he teaches courses in entrepreneurship and innovation.

David Hudson is pursuing doctoral studies and is a lecturer in the MBA program at Carleton University's Sprott School of Business in Ottawa Canada. His research focus considers entrepreneurial effort by employees and changes arising from consumer technology use in industry. Previously, David was the Vice President for Advanced Research and Technology at a large technology firm and has had an extensive career in technology development and product line management. He received Bachelor's and Master's degrees in Systems Design Engineering from the University of Waterloo.

Chris McPhee is Editor-in-Chief of the Technology Innovation Management Review and is in the Technology Innovation Management program at Carleton University in Ottawa. Chris received his $\mathrm{BScH}$ and MSc degrees in Biology from Queen's University in Kingston, following which he worked in a variety of management, design, and content development roles on science education software projects in Canada and Scotland.

Steven Muegge is an Assistant Professor at the Sprott School of Business at Carleton University in Ottawa, Canada, where he teaches within the Technology Innovation Management (TIM) program. His research interests include open and distributed innovation, technology entrepreneurship, product development, and commercialization of technological innovation.

Michael Weiss holds a faculty appointment in the Department of Systems and Computer Engineering at Carleton University, and he is a member of the Technology Innovation Management program. His research interests include open source business models, collective innovation, mashups and enduser development, product line engineering, and business patterns. Michael has published over 100 papers in conferences and journals.

Jonathan Wells is Executive Director, Research Centre in Technology Innovation, at Carleton University in Ottawa, Canada. Jonathan comes from a background of software engineering, with experience in all sizes of high-tech business, from very small startups upwards to large multinationals. He founded and ran a small software development and consultancy business for several years and subsequently worked as a project manager for HP software development teams in New Zealand, later holding the position of CIO for the Meat Inspection Branch of the NZ Canadian Food Inspection Agency. Jonathan has an undergraduate degree in Physics and Computer Science and holds an MBA from the University of Canterbury, Christchurch, NZ.

Mika Westerlund, D. Sc. (Econ.) is an Assistant Professor at Carleton University's Sprott School of Business. He previously held positions as Postdoctoral Scholar in the Haas School of Business at the University of California Berkeley and Postdoctoral Researcher in the School of Economics at Aalto University. Mika earned his doctoral degree in Marketing from the Helsinki School of Economics. His doctoral research focused on software firms' business models and his current research interests include open innovation, business strategy, and management models in high-tech and service-intensive industries. Results from his research are reported in numerous scholarly journals.

Citation: Bailetti, T., S. Bot, T. Duxbury, D. Hudson, C.

McPhee, S. Muegge, M. Weiss, J. Wells, and M. Westerlund.

2012. An Overview of Four Issues on Technology

Entrepreneurship in the TIM Review Technology

Innovation Management Review. April 2012: 28-34. 